\title{
STORAGE OF PITOMBEIRA SEEDS [Talisia esculenta (A. St. Hil) Radlk - SAPINDACEAE] IN DIFFERENT ENVIRONMENTS AND PACKAGINGS ${ }^{1}$
}

Lúcia Helena de Moura Sena ${ }^{2 *}$, Valderez Pontes Matos ${ }^{3}$, Jamile Érica de Medeiros ${ }^{4}$, Helder Henrique

Duarte Santos $^{5}$, Ana Patrícia Rocha ${ }^{2}$ and Rinaldo Luiz Caraciolo Ferreira ${ }^{6}$

\footnotetext{
${ }^{1}$ Received on 05.12.2014 accepted for publication on 03.03.2016.

${ }^{2}$ Universidade Federal Rural de Pernambuco, Programa de Pós-Graduação em Ciências Florestais, Recife, PE - Brasil. Email:<lumsena@bol.com.br>and <anarocha2205@yahoo.com.br>.

${ }^{3}$ Universidade Federal Rural de Pernambuco, Departamento de Agronomia, Área de Fitotecnia, Recife, PE - Brasil. E-mail: <vpmatos@ig.com.br>.

${ }^{4}$ Universidade Federal Rural de Pernambuco, Graduanda em Bacharelado em Agronomia, Recife, PE - Brasil. E-mail: <jamile.medeiros@hotmail.com>.

${ }^{5}$ Universidade Federal Rural de Pernambuco, Programa de Pós-Graduação em Agronomia, Melhoramento Genético de Plantas, Recife, PE - Brasil.E-mail: <helder_hds19@hotmail.com>.

${ }^{6}$ Universidade Federal Rural de Pernambuco, Departamento de Ciência Florestal, Área de Manejo Florestal, Recife, PE Brasil. E-mail: <rinaldodcfl@gmail.com>.

*Corresponding author.
}

\begin{abstract}
This paper aimed to evaluate the effect of packaging, environments, and storage periods on physiological quality of Talisia esculenta (A. St. Hil.) Radlk seeds. Seeds were conditioned in PET transparent bottle, Kraft paper bag, and transparent polyethylene bag; they were stored in chamber $\left(18{ }^{\circ} \mathrm{C} ; 50 \% \mathrm{RH}\right)$, in freezer $\left(-21 \pm 2{ }^{\circ} \mathrm{C} ; 95 \% \mathrm{RH}\right)$, and under laboratory natural environment $\left(28 \pm 5^{\circ} \mathrm{C} ; 65 \% \mathrm{RH}\right)$. They were evaluated at the $0,25^{\text {th }}, 50^{\text {th }}, 75^{\text {th }}$, and $100^{\text {th }}$ storage day for moisture content, thousand seed weight, emergence percentage, emergence rate index, length, and dry mass of shoot and root. T. esculenta seeds should be stored in chamber or laboratory natural environment, packed in polythene bag up to 25 days. The Kraft paper bag and the PET bottle cannot be used for storing T. esculenta seeds. Freezer is not recommended for storing $T$. esculenta seeds because it makes them unviable.
\end{abstract}

Keywords: Conservation; Native forest; Recalcitrant.

ARMAZENAMENTO DE SEMENTES DE PITOMBEIRA [Talisia esculenta (A. St. Hil) Radlk - SAPINDACEAE] EM DIFERENTES AMBIENTES E EMBALAGENS

\begin{abstract}
RESUMO - Este trabalho teve por objetivo avaliar o efeito da embalagem, do ambiente e periodo de armazenamento sobre a qualidade fisiológica de sementes de Talisia esculenta (A. St. Hil.) Radlk. As sementes foram acondicionadas nas embalagens: garrafa pet transparente, saco de papel Kraft e saco de polietileno transparente em ambientes: câmara $\left(18{ }^{\circ} \mathrm{C} ; 50 \%\right.$ UR do ar), freezer $\left(-21 \pm 2{ }^{\circ} \mathrm{C}\right.$; $95 \%$ UR do ar) e natural de laboratório $\left(28 \pm 5{ }^{\circ} \mathrm{C}\right.$; 65\% UR do ar). Aos 0, 25, 50, 75 e 100 dias de armazenamento foram avaliados: teor de água, peso de mil sementes, porcentagem de emergência, indice de velocidade de emergência, comprimento e massa seca da parte aérea e raiz. Sementes de T. esculenta devem ser armazenadas em câmara ou ambiente natural de laboratório, embaladas em saco de polietileno por até 25 dias. A embalagem saco de papel Kraft e garrafa pet não devem ser utilizados para armazenamento de sementes de T. esculenta. O armazenamento das sementes de pitombeira em freezer não é recomendado, pois as tornam inviáveis.
\end{abstract}

Palavras-chave:Conservação; Espécie nativa; Recalcitrante. 


\section{INTRODUCTION}

The continuous availability of viable seeds is essential to forest programs, such as reforestation and recovery of degraded areas, breeding programs in germplasm conservation for long periods, especially for endangered species, and research on technology and seed physiology (CARVALHO et al., 2008; FLORIANO, 2014). Therefore, the storage becomes basic in forming commercial plantations, because it allows using plant species in different times and different places of their origin (KOHAMA et al., 2006), ensuring the demand for seeds of species with irregular production, abundant in some years and scarce in others (CRUZ, 2012), seeking to maintain their maximum physiological, physical, and sanitary quality for future use.

Considering the desiccation tolerance and behavior during storage, seed classification was firstly proposed by Roberts (1973), establishing two seed classes: orthodox and recalcitrant. Orthodox seeds were subjected to intense dehydration process along their physiological maturity; and they can be desiccated after their dispersion without considerable damage of their structures, and can be preserved for long term. The recalcitrant seeds are dispersed with high moisture content because they did not were subjected to intense desiccation, remaining viable for short time (VIDOR, 2011); also, they show variable behavior during storage, depending on the species, environment, ripeness grade, initial physiological quality, and other factors.

Talisia esculenta (A. St. Hil.) Radlk (Sapindaceae) belongs to species with recalcitrant seeds; and it is known as pitombeira, pitomba-da-mata, pitomba-demacaco. This tree is native in Brazil, cultivated in home gardens, showing natural habitat in the upland forest of the western part of the Amazon region and in the Atlantic Forest, from Northeast to Southeast Brazil, until the Rio de Janeiro State (LORENZI et al., 2006). It has ecological, economical, and medical potential and is suitable for planting and restoring riparian forests, in natura fruit consumption, and for manufacturing derivatives rich in vitamins (VIEIRA; GUSMÃO, 2006).

There is little information regarding the conservation of recalcitrant seeds that can remain viable for only a few weeks or months (ALVES; SOUZA, 2011). In addition, many species of tropical region have recalcitrant seeds, which causes storage difficulty (VIEIRA et al., 2001); if they are dehydrated the water content below a critical level, generally high, which varies kind, the rapid loss of viability may occur and may lead to death (ROBERTS, 1973).

Different packaging types are used for storage, as bag of plastic, paper, canvas, burlap, jute or cloth and also aluminum cans, glass, and plastic packaging when well sealed (SENA; GARIGLIO, 2008). The seed conservation is also affected by the environment under which they are stored, in accordance with studies developed by Dias; Veloso (2013) about quaresmeira (Tibouchina estrellensis Raddi Cogn. - Melastomataceae) seeds, and by Souza (2013) about quinoa (Chenopodium quinoa Willd. - Amaranthaceae) seeds.

It is needed to know the right conditions for recalcitrant seed storage to keep the germination and seed vigor as long as possible because of their rapid deterioration. Considering the importance of this species and the lack of knowledge about its seed conservation, this study aimed to evaluate the effect of packaging, environment, and storage time on the physiological quality of Talisia esculenta (A. St. Hil.) Radlk seeds.

\section{MATERIALAND METHODS}

T. esculenta fruits physiologically developed were collected from 16 mother trees, located in the municipality of Abreu e Lima, Pernambuco (PE) State, Brazil (- $7^{\circ}$ 53' 17" S, -34 54' 58" W), on April 2013, with As' climate type, according to the Wilhelm Koppen classification (BELTRÃO et al., 2005). Then they were sent to the Seed Laboratory of the Agronomy Departament at the Federal Rural University of Pernambuco (UFRPE), in Recife City, Pernambuco State, Brazil.

Extraction of the seeds was carried out using the method indicated by Cardoso (2011), the pericarp sectioned in half and the aryl manual withdrawal was carried out by friction in groups of 4 fruits, adding washed sand and sieved into $5 \mathrm{~mm}$ mesh sieve, performing circular movements to remove excess of aryl. Later, the seeds were washed in running water and put to dry in the shade (laboratory environment) for $48 \mathrm{~h}$, as recommended by Alves et al. (2008), registering air temperature ranging from $26.6^{\circ} \mathrm{C}$ to $31.4{ }^{\circ} \mathrm{C}$, and relative humidity $(\mathrm{RH})$ ranging from 45 to $74 \%$.

After the drying period, seeds were placed in different packages: permeable - Kraft paper bag; semipermeable - transparent polyethylene bag of 0.1 $\mathrm{mm}$ thickness; and impermeable - polyethylene 
terephthalate (PET) transparent plastic bottle of 500 $\mathrm{mL}$ and kept there during $0,25,50,75,100$ days; they were submitted under three environments, chamber $\left(18{ }^{\circ} \mathrm{C}, 50 \% \mathrm{RH}\right)$, freezer $\left(-21 \pm 2{ }^{\circ} \mathrm{C}, 95 \% \mathrm{RH}\right)$, and laboratory $\left(28 \pm 5^{\circ} \mathrm{C}, 65 \% \mathrm{RH}\right)$.

For the seedling emergence, before the sowing, the seeds were disinfected with 5\% sodium hypochlorite solution $(\mathrm{NaClO})$ for $5 \mathrm{~min}$ and washed with deionized water. Before and after every 25 storage days, the seeds of each package in storage environment were sowed in plastic trays $(30 \times 22 \times 7 \mathrm{~cm})$, between the average sized Vermiculite ${ }^{\circledR}$ substrate, using 4 replicates of 25 seeds. The substrate was previously sterilized in autoclave set at $120^{\circ} \mathrm{C}$ for two hours, and then moistened with deionized water, taking up $60 \%$ of the substrate holding capacity.

The trays were taken to the greenhouse of the forest hotbed belonging to the Department of Forest Science, located on the Campus of UFRPE and placed on benches. The minimum and maximum temperatures recorded in the greenhouse were 22.6 and $34.4{ }^{\circ} \mathrm{C}$, respectively, and minimum and maximum relative humidity were 42.1 and $93.9 \%$, respectively.

The seed water content was determined by two replicates of $10 \pm 1.0 \mathrm{~g}$ seeds of each period, environment, and storage packaging. Seeds were cut in 3 parts of approximately $7.0 \mathrm{~mm}$ and placed in aluminum containers of $5 \times 11 \mathrm{~cm}$ and subjected to oven at $105^{\circ} \mathrm{C} \pm 3{ }^{\circ} \mathrm{C}$ for 24 hours (BRASIL, 2009), and the results were expressed in percentage (wet basis).

The weight of thousand seeds was determined by 8 replicates with 100 seeds, weighed on analytical balance with accuracy of $0.001 \mathrm{~g}$ (BRASIL, 2009).

The seedling emergence (\%) - that was carried out in a greenhouse matched the number of normal emerged seedlings up to 50 days after sowing (NAKAGAWA, 1999); the adopted emergence criterion was the epicotyl emergence with subsequent protophilus emergence, because it is a species with hypogeal type germination. Emergence rate index (ERI) - was in accordance with the formula presented by Maguire (1962). Shoot and primary root length $\left(\right.$ seedling $\left.{ }^{-1} \mathrm{~cm}\right)$ - the normal seedlings was measured with a ruler at the end of the emergence test (NAKAGAWA, 1999). Shoot and root dry mass (seedling ${ }^{-1} \mathrm{mg}$ ) - the normal seedlings of each replicate of packaging and storage environment were cut in the collar region and the shoot and root system were placed separately in Kraft paper bag, previously identified, and taken to the forced ventilation oven set at $80^{\circ} \mathrm{C}$ until reaching constant weight (CARVALHO FILHO et al., 2004), and weighed in analytical balance with a precision of $0.001 \mathrm{~g}$ up to the stabilization of results.

Data, except water content, were subjected to analysis of variance, completely randomized scheme, with factorial arrangement, and then the combined analysis of variance was carried out for the packaging and storage environments factors. For storage period, polynomial regression was performed, verifying the linear, quadratic, and cubic effects of the variables, depending on the treatments; and the significant model of higher order was selected. For statistical analysis, the SISVAR version 5.3/1999-2010 statistical program was used (FERREIRA, 2010).

\section{RESULTS}

The initial water content of T. esculenta seeds reached values of $40.65 \%$ (Table 1 ), close to that one recommended by Alves et al. (2008) for drying seeds of this species for up to 48 hours $(39.9 \%)$, while the weight of thousand seeds was 2,146.42 $\mathrm{g}$ (Coefficient of variation - $\mathrm{CV} \%=3.1 \%$ ) with approximately 466 seeds ${ }^{-1} \mathrm{~kg}$.

Among the packaging, PET bottle and polyethylene bag were the ones that allowed to keep the water content values of T. esculenta seeds closer to the original in all storage environments, unlike the observed ones for seeds stored in Kraft paper bag under chamber conditions $\left(18^{\circ} \mathrm{C}, 50 \% \mathrm{RH}\right)$ and laboratory natural environment $\left(28 \pm 5^{\circ} \mathrm{C}, 65 \% \mathrm{RH}\right)$, causing rapid moisture reduction of seeds.

Evaluating seed physiological quality during storage, reduction in the emergence of T. esculenta seedlings (Figure 1) was observed as the storage period increased, regardless of the tested environment and packaging. At the $25^{\text {th }}$ storage day, seeds stored in polyethylene bag and chamber environment $\left(18^{\circ} \mathrm{C}\right.$, $50 \% \mathrm{RH}$ ) produced $89 \%$ normal seedlings (Figure 1A), while, from seeds stored in PET bottle and Kraft paper bag, 68 and $8 \%$ of seedlings emerged, respectively; in laboratory natural environment $\left(28 \pm 5^{\circ} \mathrm{C}, 65 \% \mathrm{RH}\right)$ (Figure $1 \mathrm{~B}$ ), $82 \%$ of seedlings emerged. After this period, storage is not efficient for both storage environments,

Revista Árvore, Viçosa-MG, v.40, n.3, p.435-445, 2016

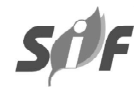


Table 1 - Moisture content (\%) of Talisia esculenta (A. St. Hil.) Radlk seeds conditioned in differents packings, environments and storage periods.

Tabela 1 - Teor de água (\%) de sementes de Talisia esculenta (A. St. Hil.) Radlk acondicionadas em diferentes embalagens, ambientes e periodos de armazenamento.

\begin{tabular}{|c|c|c|c|c|c|c|}
\hline \multirow[t]{2}{*}{ Environment } & \multirow[t]{2}{*}{ Packing } & \multicolumn{5}{|c|}{ Period (days) } \\
\hline & & 0 & 25 & 50 & 75 & 100 \\
\hline & PET bottle & 40.65 & 43.14 & 40.13 & 44.45 & 43.75 \\
\hline Chamber & Polyethylene bag & 40.65 & 42.25 & 43.33 & 45.20 & 44.17 \\
\hline \multirow[t]{2}{*}{$\left(18^{\circ} \mathrm{C} ; 50 \% \mathrm{RH}\right)$} & Kraft paper bag & 40.65 & 23.11 & 17.04 & 13.13 & 11.78 \\
\hline & PET bottle & 40.65 & 37.33 & 40.60 & 36.92 & 41.11 \\
\hline Freezer & Polyethylene bag & 40.65 & 38.15 & 41.34 & 42.74 & 38.39 \\
\hline$\left(-21 \pm 2{ }^{\circ} \mathrm{C} ; 95 \% \mathrm{RH}\right)$ & Kraft paper bag & 40.65 & 35.78 & 39.39 & 37.83 & 39.51 \\
\hline \multirow{3}{*}{$\begin{array}{l}\text { Laboratory natural } \\
\left(28 \pm 5^{\circ} \mathrm{C} ; 65 \% \mathrm{RH}\right)\end{array}$} & PET bottle & 40.65 & 42.51 & 41.12 & 42.15 & 45.76 \\
\hline & Polyethylene bag & 40.65 & 39.97 & 47.84 & 47.15 & 51.33 \\
\hline & Kraft paper bag & 40.65 & 23.35 & 22.48 & 19.99 & 16.60 \\
\hline
\end{tabular}
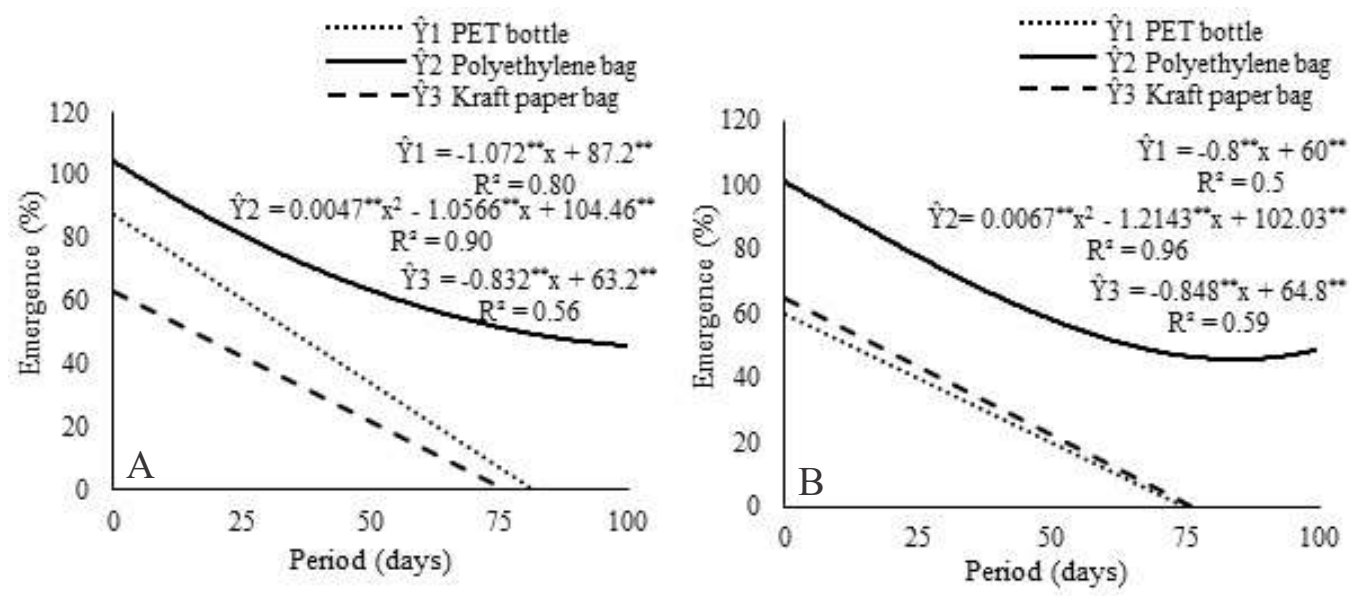

Figure 1 - Emergence (\%) of Talisia esculenta (A. St. Hil.) Radlk seedlings from conditioned seeds in differents packings, environments and storage periods. A - chumber, B - laboratory natural environment. CV $(\%)=16.96$.

Figura 1 - Emergência (\%) de plântulas de Talisia esculenta (A. St. Hil.) Radlk oriundas de sementes acondicionadas em diferentes embalagens, ambientes e periodos de armazenamento. A - câmara, B - ambiente natural de laboratório. $C V(\%)=16.96$

and only about $50 \%$ of normal seedlings were remained at $100^{\text {th }}$ storage day.

The emergence percentage of T. esculenta seedlings becomes zero after 50 storage days, when seeds were stored in a chamber $\left(18^{\circ} \mathrm{C}, 50 \% \mathrm{RH}\right)$ (Figure 1A) and packed in PET bottle and Kraft paper bag, while in laboratory natural environment $\left(28 \pm 5^{\circ} \mathrm{C}, 65 \% \mathrm{RH}\right)$, the seeds kept in PET bottle do not generate seedlings at the $25^{\text {th }}$ storage day.

The storage of T. esculenta seeds in freezer $\left(-21 \pm 2{ }^{\circ} \mathrm{C} ; 95 \% \mathrm{RH}\right)$ for 25 days resulted in drastically seed infeasibility in all of the used packaging, and was unsuitable for this species; therefore, data were not showed in figures for this storage environment for evaluated physiological quality parameters.

In the emergence rate index (Figure 2) of T. esculenta seedlings, there was reduction of rate vigor during the storage period, caused by the seedling emergence rate decreasing gradually as result of seeds stored in camera environment $\left(18^{\circ} \mathrm{C} ; 50 \% \mathrm{RH}\right)$ and laboratory natural environment $\left(28 \pm 5{ }^{\circ} \mathrm{C} ; 65 \% \mathrm{RH}\right)$, showing the effect of seed decay process, especially when stored in Kraft paper bag and PET bottle.

At the $25^{\text {th }}$ storage day, when there were $89 \%$ of emerged $T$. esculenta seedlings, the emergence rate increased from 0.86 to 0.91 for seed seedlings stored 
in chamber $\left(18^{\circ} \mathrm{C}, 50 \% \mathrm{RH}\right)$ in polyethylene packaging bag (Figure 2A). Seeds kept in laboratory natural environment $\left(28 \pm 5{ }^{\circ} \mathrm{C}, 65 \% \mathrm{RH}\right)$ and packed in polyethylene bag with $82 \%$ of emerged seedlings showed lower emergence rate $(0.69)$ (Figure $2 \mathrm{~B}$ ) at the $25^{\text {th }}$ storage day, regarding the seeds kept in the chamber.

Regarding to the length and shoot dry mass (Figure 3), it was able to establish a shoot length ratio with the dry mass of T. esculenta seedlings, obtained from seeds stored under chamber conditions $\left(18{ }^{\circ} \mathrm{C}, 50 \%\right.$ $\mathrm{RH}$ ) (Figures 4A 1-A2) and laboratory natural environment $\left(28 \pm 5{ }^{\circ} \mathrm{C}, 65 \% \mathrm{RH}\right)$ (Figures 3B1-B2).

At the $25^{\text {th }}$ and $50^{\text {th }}$ day, the T. esculenta seeds stored under chamber environment $\left(18^{\circ} \mathrm{C}, 50 \% \mathrm{RH}\right)$ and packed in polyethylene bag have produced seedlings with shoot length and dry mass measuring $12.35 \mathrm{~cm}$ and 266.71 $\mathrm{mg}$, respectively; $12.9 \mathrm{~cm}$ and $267.62 \mathrm{mg}$, respectively (Figures 3A1-A2). At the $25^{\text {th }}$ and $50^{\text {th }}$ day, when stored seeds were used in laboratory natural environment (28 $\pm 5^{\circ} \mathrm{C}, 65 \% \mathrm{RH}$ ) (Figures 3B1-B2), seedlings were obtained with shoot measuring $12.59 \mathrm{~cm}$ and $5 \mathrm{~cm}$, and dry mass of $213.81 \mathrm{mg}$ and $272.28 \mathrm{mg}$, respectively.

The T. esculenta seedlings from seeds stored up to 50 days in chamber $\left(18{ }^{\circ} \mathrm{C}, 50 \% \mathrm{RH}\right)$ and stored in polyethylene bag (Figure 4A1 ) showed gradual increase in the length of the primary root, reaching $40.9 \mathrm{~cm}$ with a further decrease in the length of the primary root of seedlings up to the $100^{\text {th }}$ storage day $(33.08 \mathrm{~cm})$. Similar behavior was observed in the root dry mass (Figure 4A2) of emerged T. esculenta seedlings at the $50^{\text {th }}$ storage day $(209.67 \mathrm{mg})$.

The $T$. esculenta seeds, which remained preserved in laboratory natural environment $\left(28 \pm 5^{\circ} \mathrm{C}, 65 \% \mathrm{RH}\right)$ and packed in polyethylene bag, have produced seedlings with primary root of greater length (Figure 4B1) up to the $50^{\text {th }}$ storage day $(37.21 \mathrm{~cm})$; seeds which remained stored after this period have produced seedlings with primary root of lower development, $32.81 \mathrm{~cm}$ and 28.41 $\mathrm{cm}$, corresponding to the $75^{\text {th }}$ and $100^{\text {th }}$ storage day. Data relating to the dry mass of root system (Figure 4B2) and to the polyethylene bag did not fit the regression models.

\section{DISCUSSION}

Figueiredo Neto et al. (2012) stated that water content oscillations in seeds undergoing laboratory natural environment may occur because of the gains and losses of air relative humidity and temperature in this environment. In addition, ingá seeds (Inga laurin (Sw) Willd. - Fabaceae, Mimosoideae) showed similar behavior to that one found for T. esculenta, regarding to the seed water content, allowing to associate humidity increase with metabolic events that occur during deterioration process as well as with increasing
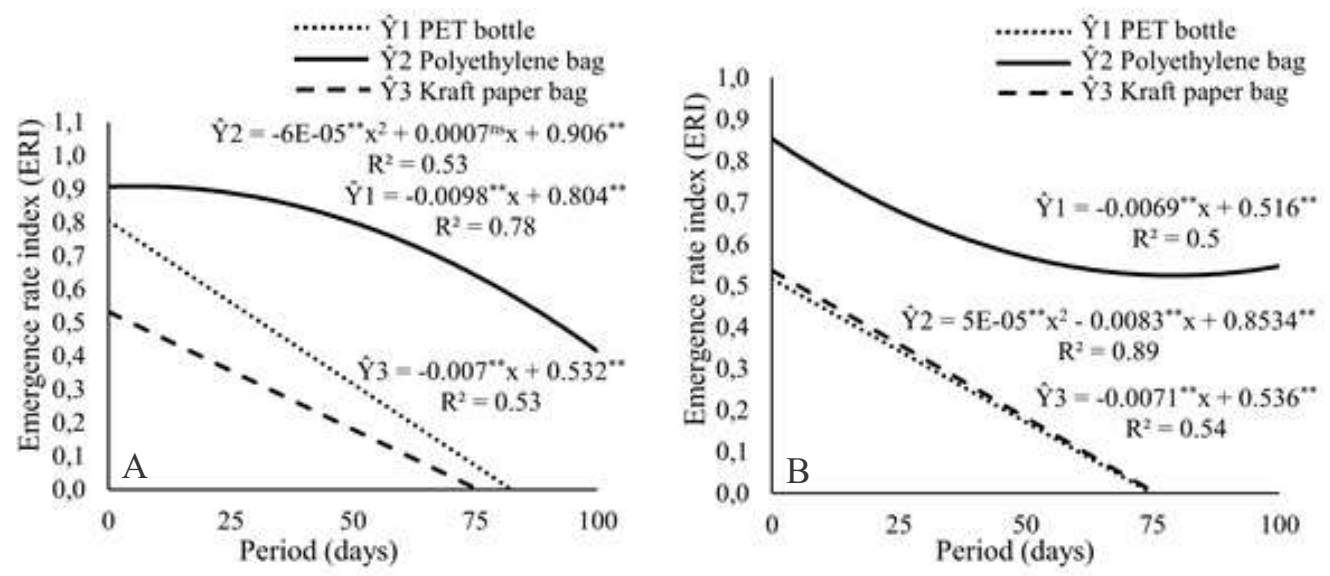

Figure 2 - Emergency rate index (ERI) of Talisia esculenta (A. St. Hil.) Radlk seedlings from conditioned seeds in different packings, environments and storage periods. A - chumber, B - laboratory natural environment CV $(\%)=29.53$.

Figura 2 - Velocidade de emergência (IVE) das plântulas de Talisia esculenta (A. St. Hil.) Radlk oriundas de sementes acondicionadas em diferentes embalagens, ambientes e períodos de armazenamento. A-câmara; $B$ - ambiente natural de laboratório. $C V(\%)=29.53$. 

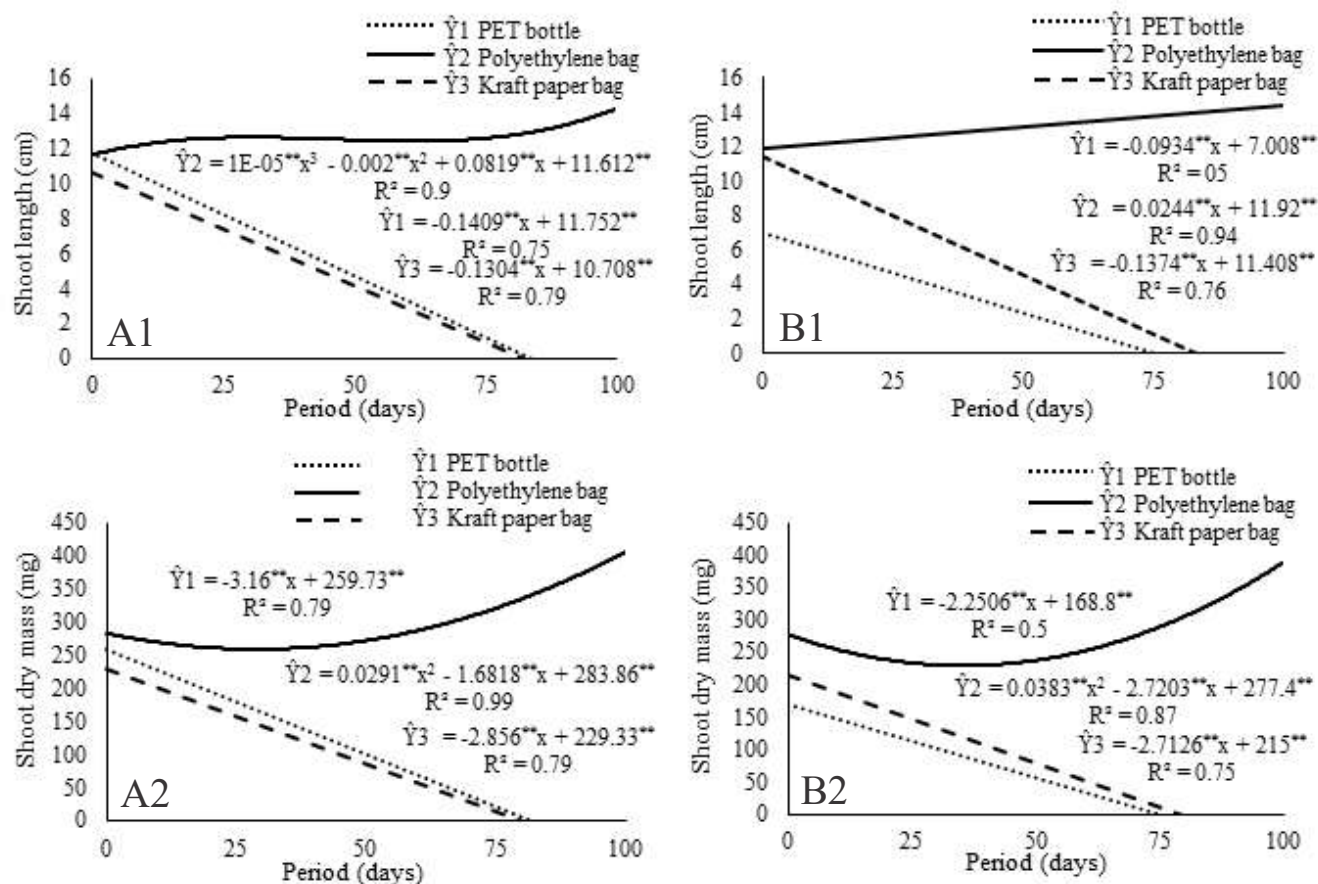

Figure 3 - Shoot length (seedling ${ }^{-1} \mathrm{~cm}$ ) and shoot dry mass (seedling ${ }^{-1} \mathrm{mg}$ ) of Talisia esculenta (A. St. Hil.) Radlk seedlings from conditioned seeds in different packings, environments and storage periods. A1, A2 - chumber, B1, B2 laboratory natural environment. C.V. $(\%)=9.59 ; 14.40$, respectively.

Figura 3 - Comprimento (cm.plântula ${ }^{-1}$ ) e massa seca (mg.plântula ${ }^{-1}$ ) da parte aérea das plântulas de Talisia esculenta (A. St. Hil.) Radlk oriundas de sementes acondicionadas em diferentes embalagens, ambientes e periodos de armazenamento. A1, A2 - câmara; B1, B2 - ambiente natural de laboratório. CV (\%) =9.59; 14.40, respectivamente.

microorganisms incidence on recalcitrant seed storage (BARROZO, 2012).

This seed behavior in relation to water content, when wrapped in Kraft paper bag, permeable packaging, can be explained by the air relative humidity variation, resulting from the time in which the experiment was carried out, climate changes, packaging permeability, and hygroscopicity presented by the seed (ULLMANN et al., 2012.); consequently, this fact causes constant adjustments in the moisture content of the stored seeds (OAK; NAKAGAWA, 2012), determinant for the decay process, since the respiratory activity increases and hence the reservations consumption too (GUEDES et al., 2012).

Vieira; Gusmão (2008), storing T. esculenta seeds in laboratory natural environment $\left(25 \pm 2{ }^{\circ} \mathrm{C}\right.$ and 68 $\pm 3 \% \mathrm{RH}$ ) for $0,15,30$, and 60 days in Kraft paper bag, found reduction in seed water content from 40 to $24 \%$ at the $15^{\text {th }}$ day after storage, resulting in decrease of seedlings emergence from 88 to $16 \%$. Results obtained in this study for T. esculenta were similar, so that at the $25^{\text {th }}$ storage day the seeds with $23 \%$ water content caused achieving only $12 \%$ of emerged seedlings.

Arruda et al. (2011) observed the viability loss in nó-de-cachorro seeds (Heteropterys tomentosa A. Juss. - Malphiguiaceae) from the $60^{\text {th }}$ storage day, packed in Kraft paper bag and under laboratory natural environment $\left(27.2 \pm 2{ }^{\circ} \mathrm{C}, 80 \% \mathrm{RH}\right)$. In marizeiro seeds (Geoffroea spinosa Jacq - Fabaceae, Papolionoideae) kept in Kraft paper bag and stored in laboratory natural conditions $\left(23.5^{\circ} \mathrm{C}\right.$ and $\left.19.2^{\circ} \mathrm{C}, 85 \% \mathrm{RH}\right)$, rapid decrease in germination and vigor was observed from the $30^{\text {th }}$ storage day (SOUZA et al., 2011).

The emergence reduction of $T$. esculenta seedlings packed in Kraft paper bag is related to water loss in recalcitrant seeds that trigger certain perishable processes such as protein denaturation, alterations of peroxidase enzymes activity, and damage to the membrane system, 

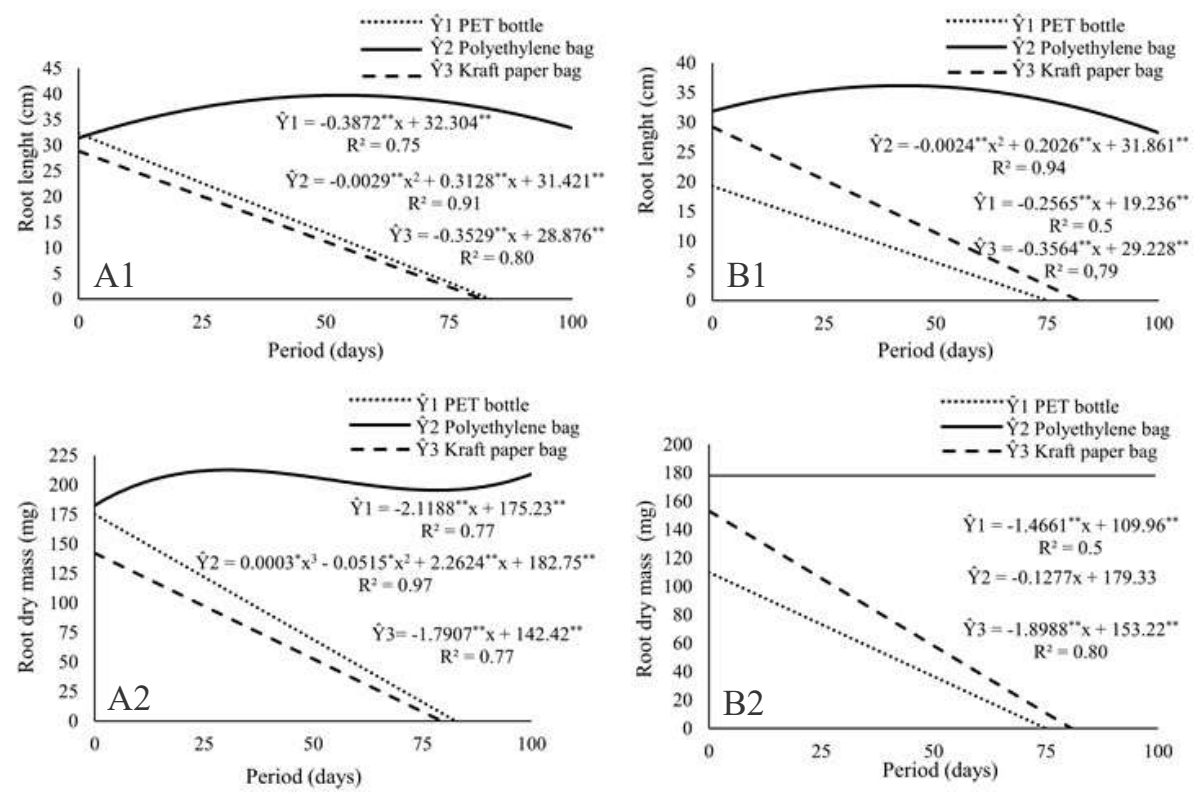

Figure 4 - Root length (seedling ${ }^{-1} \mathrm{~cm}$ ) and root dry mass (seedling ${ }^{-1} \mathrm{mg}$ ) of Talisia esculenta (A. St. Hil.) Radlk seedlings from conditioned seeds in different packings, environments and storage periods. A1, A2 - chumber, B1, B2 laboratory natural environment. CV $(\%)=19.78 ; 22.07$, respectively.

Figura 4 - Comprimento da raiz primária (cm.plântula ${ }^{-1}$ ) e massa seca do sistema radicular (mg.plântula ${ }^{-1}$ ) das plântulas de Talisia esculenta (A. St. Hil.) Radlk oriundas de sementes acondicionadas em diferentes embalagens, ambientes e periodos de armazenamento. A1, A2 - câmara; B1, B2 - ambiente natural de laboratório. CV (\%) = 19.78; 22.07 , respectivamente.

resulting in its viability loss (FONSECA; FREIRE, 2003). In the polyethylene bag and PET bottle, longevity should be related to increased moisture maintenance of seeds than packaging in Kraft paper bag (BÜLOW et al., 1994).

This reduction in emergence rate with increasing storage time occurs probably due to the consumption of the seed reserves during breathing, the deterioration by oxidation, or due to the seed increased water content, which was enough to allow increase in respiratory metabolism, because recalcitrant seeds do not suffer drying at the maturation end and are dispersed with a high water content, remaining metabolically active and sensitive to drying, so that, they can germinate right after dispersion (BARROSO, 2012). The deterioration, imperceptible in the initial stage in many cases, is expressed over time through the negative effects on the vigor (GARCIA et al., 2004).

Despite more vigorous seedlings were obtained at the $100^{\text {th }}$ storage day, $50 \%$ reduction in the number of normal seedlings occurred in this evaluated period. These dry mass values due to the higher storage period are related to the conditions of environment and package, which provided the beginning of the seed germination process that showed at the sowing time or even by less number of emerged seedlings when compared to other storage periods.

Results of this study showed differences among environments and packaging used for storing T. esculenta seeds. It is clear that there is great method diversities for storage recalcitrant seeds, even for the same species; there is no general consensus about the most appropriate method due to few existing researches with these seeds (SENA, 2014).

This way, the packaging type affects differently the seed viability (FLORIANO, 2014) regardless of the storage environment; even considering the optimal conditions of water content and temperature, the continuous deterioration process occurs in every seed, leading to gradual loss of viability and vigor (MARCOS FILHO, 2005). Therefore, the high emergence at the storage beginning does not ensure that the seed quality is maintained until the sowing time. 
As noted in the emergence of T. esculenta seedlings, the seed packaging in PET bottle favored the emergence of $68 \%$ of seed seedlings subjected to the storage chamber $\left(18^{\circ} \mathrm{C}, 50 \% \mathrm{RH}\right)$ up to the $25^{\text {th }}$ day, but when the seeds were stored in other environments and other storage periods, seedling emergence did not occur, making them unviable. This seed response to storage in the tested environments and packaging may be related to the fact that formed carbon dioxide $\left(\mathrm{CO}_{2}\right)$ was unable to exit from the packaging interior and it became toxic after a certain level of concentration; in the same way, oxygen $\left(\mathrm{O}_{2}\right)$ leads to anaerobic respiration, because it is rapidly consumed, resulting in the accumulation of toxic compounds (CARVAHO; NAKAGAWA, 2012).

In polyethylene bag, there were lot of T. esculenta seeds infested by fungus; and still under storage, there was also the emission of some seedlings. The attack of fungi increased in the course of time, but right after 25 storage days, some seeds kept in a polyethylene bag and Kraft paper bag, under chamber conditions $\left(18^{\circ} \mathrm{C} ; 50 \% \mathrm{RH}\right)$ and laboratory natural environment $\left(28 \pm 5{ }^{\circ} \mathrm{C}, 65 \% \mathrm{RH}\right)$ were already contamined. These fungi are a significant problem, especially due to the high humidity of seeds that creates favorable conditions for their development and due to the sensitivity of recalcitrant species to low temperatures used to allow their control (MARCOS FILHO, 2005), resulting in a succession of fungi promoting deterioration and elevated temperature and humidity of the infected seeds.

It is interesting, therefore, the development of researches on the use of germination inhibitors and the use of fungicidal products to better preserve the physical, physiological, and sanitary characteristics of the seeds. This fact is because, at the $100^{\text {th }}$ storage day, it was observed that fungus infestation was considerably higher than at the $25^{\text {th }}$ day, which may have caused the reduction in the emergence percentage of $100 \%$ of emerged plants, originated from the seeds prior to storage to approximately $50 \%$ in the last assessment period (100 ${ }^{\text {th }}$ day), both for chamber environment $\left(18^{\circ} \mathrm{C}, 50 \% \mathrm{RH}\right)$ and laboratory environment $\left(28 \pm 5{ }^{\circ} \mathrm{C}, 65 \% \mathrm{RH}\right)$.

In permeable packaging, Kraft paper bag, at the $25^{\text {th }}$ storage day, there was rapid deterioration process with reduction of $92 \%$ of emergence potential of $T$. esculenta seedlings when stored in chamber $\left(18^{\circ} \mathrm{C}\right.$, $50 \% \mathrm{RH})$. Seeds in this package still showed wilted, wrinkled, and brittle integument over the storage period. Such containers allow the vapor exchange among the seeds and the surrounding external environment; hence, the water content undergoes fluctuations with changes in air relative humidity and excessive drying of the integument, causing cracks, facilitating the penetration of microorganisms and loss of regulation capacity of water and gas exchange in seeds (VILLELA; PERES, 2004).

For most species, seeds will be much better preserved the lower the air temperature in the storage environment (CARVALHO; NAKAGAWA, 2012). However, because T. esculenta seeds are recalcitrant, when stored under freezer conditions $\left(-21 \pm 2{ }^{\circ} \mathrm{C} ; 95 \% \mathrm{RH}\right)$ in PET bottle, polyethylene bag, and Kraft paper bag, they became infeasible; so, this storage environment should not be used for conservation of this seed's species.

The technically adequate storage depends on the quality of stored seed, but care should be started in the field to get good quality seeds, avoiding the damage occurrence on the seeds, insect attack, and picking out the appropriate period. Furthermore, during storage, the seed water content should be kept at appropriate levels to prevent the development of pathogenic microorganisms (GOLDFARB; QUEIROGA, 2013). It is, therefore, needed to improve scientific knowledge on the physiological mechanisms recommended to the sensitivity, desiccation, and to low temperatures, to indicate efficient storage methods for recalcitrant seeds (PIROLA, 2013), since the high water content in the seeds, combined with high air relative humidity and storage environmental temperature accelerate the biological system degeneration, leading to the loss of vigor and germination capacity of seeds (AZEVEDO et al., 2003).

Therefore, the use of polyethylene bag under chamber $\left(18{ }^{\circ} \mathrm{C}, 50 \% \mathrm{RH}\right)$ or laboratory natural environment $\left(28 \pm 5{ }^{\circ} \mathrm{C}, 65 \% \mathrm{RH}\right)$ was recommend for T. esculenta seeds for 25 days, when the seeds showed water content of 42.25 and $39.97 \%$ (89 and $82 \%$ emerged seedlings, respectively) or up to the $50^{\text {th }}$ storage day, when lower percentage of seedling emergence ( 66 and $52 \%$, respectively) was obtained, but with production of vigorous seedlings. However, it would be interesting to store seeds of this species in laboratory natural environment due to the low cost for their maintenance, since this process does not require electricity and specific 
equipment; however, it is recommended that it occurs soon after harvesting whenever possible, because it is a recalcitrant seed.

Additional studies are needed to create storage conditions that will favor the conservation of the viability of recalcitrant seeds for the largest possible period, because this information is important for seedling production programs to meet the growing demand, particularly for recovery projects of degraded areas (CARVALHO et al., 2008).

\section{CONCLUSIONS}

The T. esculenta seeds must be stored up to the $25^{\text {th }}$ day in chamber environment $\left(18^{\circ} \mathrm{C}, 50 \% \mathrm{RH}\right)$ or laboratory natural environment $\left(28 \pm 5^{\circ} \mathrm{C}, 65 \% \mathrm{RH}\right)$ and packed in polyethylene bag.

T. esculenta seeds do not withstand temperatures of $-21 \pm 2{ }^{\circ} \mathrm{C}$ and $95 \%$ relative humidity, regardless of the used package.

The Kraft paper bag and PET bottle must not be used for T. esculenta seeds storage because they cause reduction on seedling vigor.

\section{REFERENCES}

ALVES, E.U.; SILVA, K.B.; BRUNO, R.L.A.; ALVES, A.U.; CARDOSO, E.A.; GONÇALVES, E.P.; BRAZ, M.S.S. Comportamento fisiológico de sementes de pitombeira (Talisia esculenta (A. ST Hil) Radlk) submetidas à desidratação. Revista Brasileira de Fruticultura, v.30, n.2, p.509-516, 2008.

ALVES, K.C.C.L.F.; SOUZA, P.A. Influência do tratamento fungicida $e$ da temperatura sobre a qualidade fisiológica de sementes recalcitrantes do cerrado durante o armazenamento. 2011. 5p. Available in: http://eventos.uft.edu.br/ files/imports/vii ci ent/documentos/index01/ db57cd0a3f6212c351aa2fa85b8543cb/1183.pdf. Accessed on: 20 jun. 2015.

ARRUDA, J.B.; COELHO, M.F.B.; AZEVEDO, R.A.B.; ALBUQUERQUE, M.C.F. Armazenamento de sementes de Heteropterys tomentosa por diferentes períodos, embalagens e ambientes. Revista de Biologia e Ciências da Terra, v.11, n.2, p.1-9, 2011.
AZEVEDO, M.R.Q.A.; GOUVEIA, J.P.G.; TROVÃO, D.M.M.; QUEIROGA, V.P. Influência das embalagens e condições de armazenamento no vigor de sementes de gergelim. Revista Brasileira de Engenharia Agrícola e Ambiental, v.7, n.3, p.519-524, 2003.

BARROSO, L.M. Tecnologia de sementes de Inga laurina (Sw.) Willd. 2012. 110f. Tese (Doutorado em Agronomia) - Universidade Federal da Paraíba, Areia, 2012.

BELTRÃO, B.A.; MASCARENHAS, J.C.; MIRANDA, J.L.F.; SOUZA JUNIOR, L.C.; GALVÃO, M.J.T.G.; PEREIRA, S.N. Projeto cadastro de fontes de abastecimento por água subterrânea: Diagnóstico do município de Abreu e Lima, estado de Pernambuco. Recife: CPRM/PRODEEM, 2005. 11p. Available in: http://www.cprm.gov.br/rehi/ atlas/ pernambu co/relatorios/AELI001.pdf. Accessed on: 14 out. 2013.

BRASIL. Ministério da Agricultura, Pecuária e Abastecimento. Regras para análise de sementes. Brasília: MAPA/ACS, 2009. 395p.

BÜLOW, J.F.W.; CARMONA, R.; PARENTE, T.V. Armazenamento e tratamento de sementes de pitanga-vermelha-do-cerrado (Eugenua calycina) Pesquisa Agropecuária Brasileira, v.29, n.6, p.961-970, 1994.

CARDOSO, E.A. Qualidade fisiológica de sementes de pitombeira (Talisia esculenta (St. Hil) Radlk). 2011. 54f. Dissertação (Mestrado em Agronomia) - Universidade Federal da Paraíba, Areia, 2011.

CARVALHO FILHO, J.L.S.; ARRIGONI-BLANK, M.F.; BLANK, A.F. Produção de mudas de angelim (Andira flaxinifolia Benth.) em diferentes ambientes, recipientes e substratos. Revista Ciência Agronômica, v.35, n.1, p.61-67, 2004.

CARVALHO, L.R.; DAVIDE, A.C.; SILVA, E.A.A.; CARVALHO, M.L.M. Classificação de sementes de espécies florestais dos gêneros Nectandra e Octea (Lauraceae) quanto ao comportamento no armazenamento. Revista Brasileira de Sementes, v.30, n.1, p.1-9, 2008.

Revista Árvore, Viçosa-MG, v.40, n.3, p.435-445, 2016 
CARVAlHO, N.M.; NAKAGAWA, J. Sementes: ciência, tecnologia e produção. Jaboticabal: FUNEP, 2012. 590p.

CRUZ, R.J.L. Implantação de um viveiro florestal para produção de mudas nativas (Floresta Ombrófila Mista). 2012. 26f. Projeto (Curso de Graduação em Ciências Rurais) - Universidade Federal de Santa Catarina, Curitibanos, 2012.

DIAS, G.S.; VELOSO, M.D. Viabilidade da semente de Tibouchina estrellensis (Melastomataceae) após armazenamento em ambientes diferentes. 2013. Available in: http:// www.botanica.org.br/trabalhos-cientificos/ 64CNBot/resumo-ins 19702-id4932.pdf. Accessed on: 18 set. 2014 .

FERREIRA, D.F. Sisvar: versão 5.3. Lavras: UFLA, 2010.

FIGUEIREDO NETO, A.; LIMA, M.S.; SILVA, M.F.; DANTAS, B.F.; TEIXEIRA, R.A.

Armazenamento e qualidade fisiológica de sementes de abóbora. Revista Brasileira de Agropecuária Sustentável, v.2, n.2, p.44-50, 2012.

FLORIANO, E.P. Armazenamento de sementes florestais. Revista da madeira. 139ed. Available in: http://www.remade.com.br/br/ revistadamadeira_materia.php?num $=1755 \&$ s ubject=Mudas\&title $=$ Armazenamento $\% 20 \mathrm{de} \% 20$ seme ntes\%20florestais. Accessed on: 2 dez. 2014.

FONSECA, S.C.L.; FREIRE, H.B. Sementes recalcitrantes: problemas na pós-colheita. Bragantia, v.62, n.2, p.297-303, 2003.

GARCIA, D.C.; BARROS, A.C.S.A.; PESKE, S.T.; MENEZES, N.L. A secagem de sementes.

Ciência Rural, v.34, n.2, p.603-608, 2004.

GOLDFARB, M.; QUEIROGA, V.P. Considerações sobre o armazenamento de sementes.

Tecnologia \& Ciência Agropecuária, v.7, n.3, p.71-74, 2013.

GUEDES, R.S.; ALVES, E.U.; BRUNO, R.L.A.; GONÇALVES, E.P.; COSTA, E.G.; MEDEIROS, M.S.
Armazenamento de sementes de Myracrodruon urundeuva Fr. All. em diferentes embalagens e ambientes. Revista Brasileira de Plantas Medicinais, v. 14, n.1, p.68-75, 2012.

KOHAMA, S.; MALUF, A.M.; BILIA, D.A.C.; BARBEDO, C.J. Secagem e armazenamento de sementes de Eugenia brasiliensis Lam. (grumixameira). Revista Brasileira de Sementes, v.28, n.1, p.72-78, 2006.

LORENZI, H.; SARTORI, S.; BACHER, L.B.; LACERDA, M. Frutas brasileiras e exóticas cultivadas (de consumo in natura). Nova Odessa: Instituto Plantarum, 2006. 294 p.

MAGUIRE, J.D. Speed of germination-aid in selection and evaluation for seedlings emergence and vigor. Crop Science, v.2, n.2, p.176-177, 1962.

MARCOS FILHO, J. Fisiologia de sementes de plantas cultivadas. Piracicaba: FEALQ, 2005. 495p.

NAKAGAWA, J. Testes de vigor baseados no desempenho das plântulas. In: KRZYZANOWSKI, F.C.; VIEIRA, R.D.; FRANÇA NETO, J.B. Vigor de sementes: Conceitos e testes. Londrina: ABRATES, 1999. p.2 1-2. 24.

PIROLA, K. Sementes de oito fruteiras nativas do bioma floresta com araucária. 2013. 129f. Dissertação (Graduação em Agronomia) - Universidade Tecnológica Federal do Paraná, Pato Branco, 2013.

ROBERTS, E.H. Predicting the storage life of seed. Seed Science and Technology, v.1, n.3, p.499-514, 1973.

SENA, C.M.; GARIGLIO, M.A. Sementes florestais: colheita, beneficiamento e armazenamento. Natal: MMA/PNF, 2008. 28p. (Guias técnicos, 2)

SENA, L.H.M. Conservação de sementes e produção de mudas de pitombeira (Talisia esculenta (A. St. Hil.) Radlk.). 2014. 122f. Dissertação (Mestrado em Ciências Florestais) - Universidade Federal Rural de Pernambuco, Recife, 2014. 
SOUZA, F.F.J. Qualidade fisiológica de sementes de quinoa (Chenopodium quinoa Willd.) armazenadas em diferentes ambientes e embalagens. 2013. 64f.

Dissertação (Mestrado em Engenharia Agrícola) Universidade Estadual de Goiás, Anápolis, 2013.

SOUZA, V.C.; ANDRADE, L.A.; CRUZ, F.R.; FABRICANTE, J.R.; OLIVEIRA, L.S.B.

Conservação de sementes de marizeiro (Geoffroea spinosa Jack) utilizando diferentes embalagens e ambientes. Ciência Florestal, v.21, n.1, p.93-102, 2011.

ULLMANN, R.; CHAVES, T.H.; GONÇALVES, D.N.; BESSA, J.V.; KESTER, A.N. Influência de diferentes condições de armazenamento no teor de água das sementes de girassol. 2012. 3p. Available in:http://rioverde.ifgoiano.edu.br/wp-content/ uploads/dppg/resumos/pos-graduacao/ cienciasagrarias/Influ \%C3\%AAncia-de-dif erentes-condi $\% \mathrm{C} 3 \% \mathrm{~A} 7 \% \mathrm{C} 3 \% \mathrm{~B} 5 \mathrm{es}-\mathrm{de}-$ armazenamento-no-teor-de- $\% \mathrm{C} 3 \% \mathrm{~A} 1$ gua-dassement es-de-girassol.pdf. Accessed on: 20 jul. 2014.
VIDOR, M.A. Recomendações técnicas para uso dos recursos genéticos da Epagri. 2011. 118p.

VIEIRA, A.H.; MARTINS, E.P.; PEQUENO, P.L.L.; LOCATELLI, M.; SOUZA, M.G. Técnicas de produção de sementes florestais. Rondônia: Embrapa/CPAF, 2001. 4p. (Circular técnico, 205)

VIEIRA, F.A.; GUSMÃO, E. Biometria, armazenamento de sementes e emergência de plântulas de Talisia esculenta Raldk.

(Sapindaceae). Ciência e Agrotecnologia, v.32, n.4, p.1073-1079, 2008.

VIEIRA, F.A.; GUSMÃO, E. Uso da giberelina na emergência de plântulas de Talisia esculenta (A.St.Hil) Raldk. Revista Ciência Eletrônica de Engenharia Florestal, v.4, n.8, p.1-10, 2006.

VILLELA, F.A.; PERES, W.B. Coleta, beneficiamento e armazenamento. In: FERREIRA, A. G.; BORGHETTI, F. Germinação: do básico ao aplicado. Porto Alegre: Artmed, 2004. p.265-281. 